\title{
The kingdom of heaven and Matthew 10
}

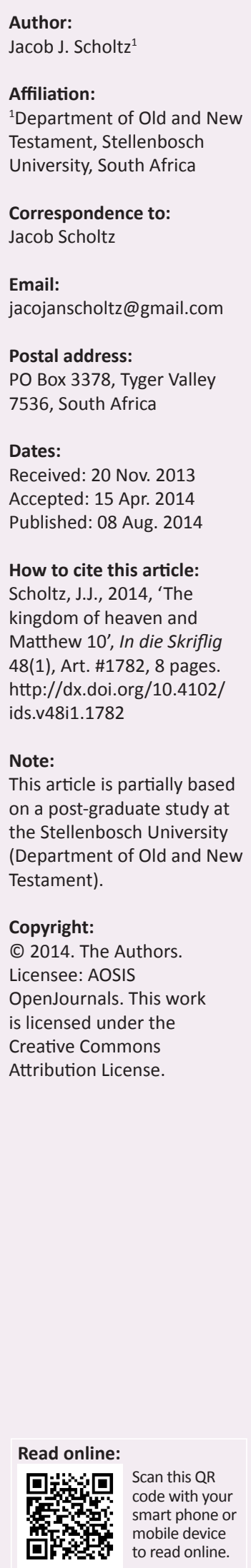

This article proposes that the mission discourse in Matthew 10 is a single mission assignment that covers two distinct time periods when the gospel of the kingdom is preached. This assignment commenced during Christ's first advent when the 12 apostles preached the gospel of the kingdom only in Israel. However, as a result of 'this generation' committing the unpardonable sin, this assignment became postponed until it will be resumed in the Tribulation when the coming King will authorise Jewish messengers to preach the gospel of the kingdom again - this time as a witness to all the nations. Based on this view of the mission discourse in Matthew 10, this article proposes a chiastic structure for Matthew 9:36-11:1a. Each section of this text will then be briefly discussed. Although the Church can make applications from this discourse, it is argued that Matthew 10:5b-42 does not refer to the Church age.

Die koninkryk van die hemele en Matteus 10. Hierdie artikel bespreek die sendingdiskoers in Matteus 10 en beweer dat dit ' $n$ enkele sendingopdrag is wat twee diskrete tydperiodes dek wanneer die evangelie van die koninkryk verkondig is. Hierdie sendingopdrag is tydens Christus se eerste koms aan die 12 apostels gegee om die evangelie van die koninkryk net in Israel te verkondig. Omdat 'hierdie geslag' die onvergeeflike sonde gedoen het, is hierdie sendingopdrag uitgestel en sal hervat word tydens die Verdrukking wanneer die komende Koning Joodse boodskappers sal magtig om weer die evangelie van die koninkryk te verkondig - hierdie keer tot getuienis vir al die nasies. Hierdie artikel stel 'n chiastiese struktuur vir Matteus 9:36-11:1a voor wat gebaseer is op hierdie siening van die sendingdiskoers in Matteus 10. Daarna word elke afdeling van die teks kortliks bespreek. Alhoewel die Kerk toepassings uit hierdie diskoers kan maak, word geargumenteer dat Matteus 10:5b-42 nie na die Kerk-era verwys nie.

\section{Introduction}

Not only is the mission discourse in Matthew 10 described as 'peculiarly difficult', but verse 23 is said to be 'among the most difficult in the NT canon' (Carson 1995:240, 250). Based on the prohibition not to go to the Gentiles or Samaritans, but only to Israel (Mt 10:5b-6), many commentators conclude that Matthew 10:5b-15 involves the preaching of the 12 apostles to Israel during Christ's first advent (France 2007:380; Carson 1995:241; Hagner 2000:262). The period to which Matthew 10:16-42 refers, particularly 10:16-23, however, is variously viewed as either (1) the Church age and the Tribulation (Nolland 2005:427-429); (2) the time from Pentecost until the destruction of Jerusalem in 70 AD (Carson 1995:252-253; Hagner 2000:278-280); or (3) the period of the Tribulation only (Wiersbe 1980:87-89; Toussaint 1980:141-142). ${ }^{1}$ The Tribulation is viewed from a pre-millennial perspective as a period of seven years immediately preceding the return of the Son of Man, comprising two consecutive periods of three and a half years each - the latter called 'the Great Tribulation' by Jesus (Mt 24:21; cf. Toussaint 1980:141).

The purpose of this article is, firstly, to comment from a pre-millennial perspective on the kingdom of heaven as it may be understood in Matthew 1-13; secondly, to argue that Matthew's mission discourse (Mt 10:5b-42) is a single assignment that covers two distinct time periods when the gospel of the kingdom is preached; and thirdly, to propose a chiastic structure for Matthew 9:36-11:1a. Afterwards it briefly discusses each section of this text in accordance with the proposals.

\section{The kingdom}

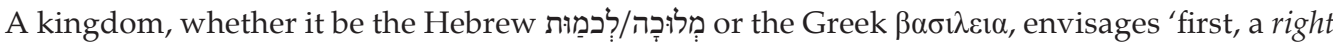
to rule; second, a rule; third, a realm to be ruled; and fourth, the exercise of the function of rulership' 
(Barrick 2012:176). Even though the kingdom of God is 'in a certain important sense, the grand central theme of all Holy Scripture' (McClain 1959:4-5), Selman (1989:162) notes that the phrase 'kingdom of Yahweh' appears only 15 times in the Old Testament in Psalm 22:28; 103:19; 145:11-13; Obadiah 21; Daniel 2:44; 4:3; 4:31; 6:26; 7:14, 18, 27; 1 Chronicles 17:14; 28:5; 29:11 and 2 Chronicles 13:8. Since an understanding of kingdom of heaven and the contingency surrounding its establishment are important to an interpretation of Matthew $10: 5 b-42$, a brief review of the kingdom is required. Using the aforementioned 15 references, what can be inferred about the kingdom of Yahweh? If this is combined with other Old Testament revelation, how would Jesus' 12 apostles have understood the kingdom of heaven about which they were authorised to preach (Mt 10:7)?

The kingdom of Yahweh is everlasting and universal over all in heaven and on earth; the kingdom, the throne, power, glory, majesty and victory belongs to Yahweh (1 Chr 29:11; Ps 103:19; 145:13). God therefore rules as king over his eternal and universal kingdom. Beacham (1996:235; cf. McClain 1959:19-21) defines the eternal or universal kingdom of God as 'God's macrocosmic rule through his exclusive, sovereign dominion over all of creation, a rule without pause or end'.

Although Yahweh is enthroned in heaven overhis everlasting kingdom, encompassing all of creation, this kingdom is also 'in the hands of the sons of David' (2 Chr 13:8) and God has promised that a descendant of David will be established 'in My house and in My kingdom forever; and his throne shall be established forever' (1 Chr 17:14). It appears that a more limited divine kingdom exists, an earth-oriented, timerelated, ethnic-centred kingdom which can be called the mediatorial kingdom of God (Beacham 1996:235; cf. McClain 1959:19-21). According to Fruchtenbaum (1989:610), one form of the mediatorial kingdom of God is the theocratic kingdom, defined as 'God's rule over Israel'. This kingdom moved through a mediatorial and monarchical phase in Israel's history.

The theocratic kingdom ended with the Babylonian captivity and yet, the kingdom of Yahweh will still be set up on earth. The Messiah will mediate the rule of God in history on earth, before this earthly kingdom will merge with God's eternal kingdom (Dn 2:44; 7:14, 18, 27). God revealed that four gentile empires would rule on earth, but at the end of the empires God would set up a kingdom, which will never be destroyed (Dn 2:44; 7:14). When the messianic kingdom is established, it will crush all those gentile kingdoms of the earth and will stand forever (Dn 2:44). The greatness of all the earthly kingdoms will be given to Christ and to the saints of the Most High (Dn 7:14, 18, 27).

What further revelation about the history of the mediatorial kingdom of God on earth has been given in the Old Testament? Pentecost (1995:28-50; cf. McClain 1959:41-49) traces God's mediatorial kingdom program (as administered through God's appointed representatives) and covenant promises from Adam until the judgment at the tower of
Babel when God dispersed the nations. God, then, initiated a new beginning through Abram as the father of a new nation; a nation through which theocratic government was to be mediated. McAvoy (1996) remarks that the unconditional Abrahamic covenant not only governs God's entire programme for Israel and the nations, but essentially consists of three basic aspects of land, seed and blessing:

The Palestinian covenant (Deut. 28-30) amplifies the land aspect of the Abrahamic covenant. The Davidic covenant (2 Sam. 7:8-17) amplifies the seed aspect, and the new covenant (Jer. 31:27-37; Ezek. 36:22-32) amplifies the blessings aspect. (p. 27)

By calling Abram, God segregated an ethnic people as part of his purpose on earth. Later, when the conditional Mosaic covenant was established at Sinai, this ethnic group became a theocratic body politic amongst those whom God dwelt and ruled (Beacham 1996:235-236). Thus was it the beginning of the theocratic kingdom, but this kingdom ended even though Israel eventually regained its political identity after the Babylonian captivity. However, as Beacham (1996:236) points out 'God was not finished with this kingdom. The Old Testament prophets who had forecasted its demise also consistently foretold its consummate restoration' (Lv 26:40-46; Ezk 11:14-20; Hs 1:10-11). The prophets prophesied that when the Messiah came, he would set up a kingdom on earth and rule as King, hence the term Messianic kingdom. Moreover, Old Testament prophecies (see e.g. Is 32:15-20; 44:3-5; Jr 31:31-34; Ezk 39:25-29; J1 2:28-3:1; Zch 12:8-13:1) connect an outpouring of the Holy Spirit with the national salvation and restoration of Israel immediately prior to the establishment of the Messianic kingdom (cf. Ger 2004:24). This kingdom will be a literal, earthly kingdom ruled by Jesus from the throne of David in Jerusalem over all the tribes of Israel (Stallard 2000:136).

So entrenched was the expectation of the literal, earthly and national character of the kingdom of heaven that some Pharisees and Sadducees ignored the spiritual requirements for entrance into it, erroneously thinking that they qualified automatically, because they were physical descendants of Abraham (Mt 3:7-10; cf. Edersheim 1993:188). Jesus did not redefine this Old Testament understanding of the kingdom to mean something only spiritual. If such were the case, we could reasonably expect that a definition of the kingdom would have been presented in the Gospels. It is, however, not the case. Moreover, if Jesus came to present only a spiritual kingdom, one may ask why the gospel of the kingdom was preached only to Israel during Christ's first advent (Mt 10:5-7; 15:24). Stallard (2000) convincingly argues:

It would be exceedingly anachronistic to read back into the OT any later post-Christian historical developments of a kingdomin-the-heart idea or rulership of God in the world through the church. The burden of proof is on those who wish to diminish the aspect of Jewish expectation. (p. 138)

It is submitted that the Jewish people, listening to John the Baptist, Jesus and the 12 apostles (Mt 3:2; 4:17, 23; 9:35; 10:7), expected a restoration of the theocratic kingdom on earth by the Messiah, that is - and can hardly be anything but - the Messianic kingdom. 


\section{The context before Matthew 10}

From chapters 4 to 10 of Matthew, Jesus' words and his miracles serve to authenticate his person (he is the Messiah) and his message (the gospel of the kingdom) to Israel (cf. Fruchtenbaum 1989:616). When the King's public ministry starts, he preaches the gospel of the kingdom (Mt 4:17), disciples are called (Mt 4:18-22) and the King's public ministry is summarised (Mt 4:23-25). Then Matthew presents how the King authenticates his messianic claims through his words and a series of miracles (Mt 5:1-9:34). This is followed by another summary of the King's public ministry (Mt 9:35), the calling and authorisation of the King's messengers (Mt 9:36-10:1-5a), sent to preach the gospel of the kingdom (Mt 10:5b-11:1a). ${ }^{2}$

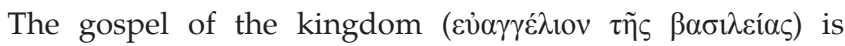
preached only to Israel (Mt 3:2; 4:17, 23; 9:35; 10:5-7; 15:24), because the unconditional Abrahamic, Land, Davidic and New covenants as well as the conditional Mosaic covenant belong to Israel. The content of the gospel in the mission discourse holds the good news that the eschatological, earthly messianic kingdom was near, conditioned by individual and national repentance, for the people of Israel was 'to turn from their sins to God in anticipation of their Messiah' and, consequently, 'if it will accept its King, Israel will have its kingdom. Therefore, the King is concerned with manifesting His presence, but only as the Son of David' (Toussaint 1980:61, 138). It is required that Israel accepts Jesus as the Christ, the Son of the living God (cf. Mt 16:16). The 12 apostles needed to go to Israel announcing 'to that nation that her King had arrived. Israel herself needed to come to faith before blessings could flow out from Israel to the nations of the earth' (Pentecost 1991:87, 193). Toussaint (1994:232) boldly states: 'The whole world could turn to Christ, but until Israel accepts Jesus as her Messiah, the millennial kingdom will not come.'

\section{The contingency of the unconditional Davidic covenant}

The requirement that Israel must accept Jesus as the Christ before the kingdom of heaven will be established in terms of the unconditional Davidic covenant is often objected to. What does it mean for a covenant to be unconditional? Unconditional promises made by God depend on God for their fulfilment entirely apart from the merit or response of the receiver (Pentecost 1995:59). Is the Davidic covenant unconditional? It is submitted that it is indeed unconditional, because David's house, kingdom and throne will be established forever, even if some of his descendants needed chastening (2 Sm 12-16). Not only are the Davidic covenant promises called eternal (2 Sm 23:5; Ps 89:1-52; Is 55:3), but these promises culminate in an eternal seed-descendant, the Son of David who is Lord (Mt22:41-45; cf. 2Chr 17:10-14). Can unconditional covenants contain conditional sub-clauses? Pentecost (1995:143) states that unconditional promises can have conditional sub-clauses, for example, even though the Davidic covenant can never be abrogated or annulled, descendants of David did not continually occupy the throne. Toussaint (1994:226) asks if 'conditionality is implied in certain prophetic pronouncements, how can anyone know if unconditional promises exist? Can conditionality vitiate any and all promises?' Peters (1972) provides some points that seem useful for identifying predictions that will unconditionally be fulfilled (as opposed to those that are merely conditional):

1. Predictions that are bound up with the Divine Plan of Redemption, as e.g. those referring to Christ's birth, life, death, etc. ... 3. Those that are incorporated in the Covenants, as e.g. the Abrahamic and Davidic covenants. ... 10. Those that relate to the establishment of the Kingdom of God, being a revelation of God's will and pleasure respecting redemptive ordering. 11. Those that describe the final restoration of the Jewish nation, this being ... essential to secure the manifestation of the Kingdom and the Salvation of the Gentiles. (p. 177)

Even though the Son of David received the right to rule the kingdom of heaven in Israel (cf. Mt 3:16-17; Lk 1:32-33), his exercise of this rule was contingent upon Israel accepting him as the messianic King (Dt 18:15-19). Once Christ established the kingdom in terms of the Davidic covenant, his rule will never end (Dn 2:44; 7:14). Could the rejection of Christ by the generation in Israel during Christ's first advent annul or abrogate God's unconditional promises? This can never be! Contingency as part of an unconditional promise may mean that the timing of the fulfilment is based on the sovereignty of God, the influence of the Spirit of God and humanity's (in this case especially Israel's) responsibility for repentance (Toussaint \& Quine 2007:131).

As there is only one Messiah but two comings, contingency is evident when considering the role of the forerunner. Although he fulfilled prophecy (Mt 3:3), John the Baptist clearly stated that he was not Elijah (Jn 1:21). John came in the spirit and power of Elijah, but he was not the person, Elijah (Lk 1:17); John the Baptist was not on the Mount of Transfiguration with Christ (Mt 17:3). If Israel was willing to accept John the Baptist, he would have been Elijah who was to come, but because they rejected him, he was not Elijah (Mt 11:14). Before Christ's second coming, Elijah will indeed come and restore all things in fulfilment of prophecy (Mt 17:11-13; cf. Ml 4:5-6; Barbieri 1983:44, 60; Toussaint 1980:211).

What does the Old Testament reveal would have happened if Israel had accepted Jesus? After noting that the eschatological programme of the Old Testament did not have the Church age in view, Toussaint (1980; cf. Constable 2014:170) states:

The program of the Lord in case of His acceptance by Israel would be in this order: (1) the acceptance of Jesus as the Messiah, (2), the cross, (3), the seven years of Jacob's trouble, and (4) the return of the Messiah to establish the kingdom. (p. 64)

Regarding step 2, the timing of Christ's cross was not contingent. Constable (2014:170) emphasises that, if the 
Jews accepted their Messiah, Christ would still have died on the cross and experienced resurrection and ascension in fulfilment of many Old Testament prophecies. For that reason, Toussaint (1980:64) states: 'One can only conclude that Christ came to offer the kingdom by way of the cross.' Constable (2014) anticipates this question:

Since the Jews rejected Jesus' offer of the kingdom - was His offer genuine? Had God not already determined that Israel would reject her Messiah? Jesus' offer of the kingdom was just as genuine as any gospel offer of salvation to someone who rejects it. (p. 54) $)^{3}$

The length of the period between the cross or ascension of the Lord Jesus (step 2) and the start of the Tribulation period (step 3) is undefined. In view of the fact that the offer of the kingdom was genuine and that John the Baptist could have been Elijah if Israel would have accepted him (Mt 11:14), followed by the acceptance of the King and his offer of the kingdom of heaven, the inference is that the period between Christ's ascension and the start of the Tribulation period might have been short. However, something different happened.

\section{The rejection in Matthew 11-12}

With the benefit of hindsight, Israel's response to the King is revealed in Matthew 11 and 12. Not only is Christ's messenger implicitly rejected, but this generation's rejection of Christ becomes evident in cities and God the Father hides these things - the mighty works of Christ - from the wise and understanding (Mt 11:16-25). Whereas Matthew 11 sketches it implicitly, Matthew 12 presents an explicit rejection of Jesus and a plot to destroy him (Mt 12:14). However, following a messianic miracle, the time for a decision is reached when the crowd asks: 'Could this be the Son of David?' (Mt 12:22-23).

An irrevocable turn is made once this generation in Israel, led by religious leaders, commits the unpardonable sin (Mt 12:24, 31-32). National repentance and salvation of this generation became impossible, because the work of the Holy Spirit, done through Jesus, was blasphemed. Even though this generation's 'full rejection of Him did not occur until later, the die was cast' (Barbieri 1983:48; cf. Beacham 1996:236). Because the Son of David was not accepted as the Messiah, the establishment of the kingdom of heaven, in terms of the Davidic covenant, is postponed. This does not mean that Israel, as a nation, is forever cast aside, or has lost the unconditional covenants that God gave her (cf. Rm 9:4; 10:1-2). It neither means that individual Jews, living in that period, could not still escape judgment by repenting and identifying with Jesus Christ in baptism (Mt 12:31, 39-40; cf. Ac 2:38-40). It is, however, submitted that 'this generation' in the history of the nation Israel, committed the unpardonable sin, as Fruchtenbaum (1989; cf. McClain 1959:315-316; Toussaint 1980:165; Pentecost 1991:207) explains:

The content and definition of the unpardonable sin is the national rejection of the Messiahship of Jesus by Israel while He was

3.Mcclain (1959:344) adds: Those who cavil at the idea of an offer which is certain to be rejected betray an ignorance, not only of Biblical history (cf. Isa 6:8-10 and Ezek 2:3-7), but also of the important place of the legal proffer in the realm of jurisprudence.' physically present on the basis that He was demon possessed. This sin is unpardonable, and judgment was set. The judgment came in the year A.D. 70 with the destruction of Jerusalem and the Temple and the world-wide dispersion of the Jewish people. It was a national sin committed by the generation of Jesus' day, and for that generation the sin was unpardonable. From this point on a special emphasis is placed on this generation in the gospels, for it was guilty of a very unique sin. At this point, His offer of the Messianic kingdom was rescinded. (p. 617)

\section{Consequences of the unpardonable sin}

Based on the understanding that the offer of the messianic kingdom in terms of the Davidic covenant was rescinded, one consequence of the unpardonable sin may be that the content of the gospel changes for a time from the preaching of the gospel of the kingdom that emphasises Christ and the nearness of the Davidic kingdom to the gospel that emphasises Christ's death, burial and resurrection. It is submitted that there is only one gospel, but, as Ryrie (2007) argues, the content of the gospel has changed over the course of history:

The basis of salvation in every age is the death of Christ; the requirement for salvation in every age is faith; the object of faith in every age is God; the content of faith changes in the various dispensations. (p. 134)

Couch (2000:196) emphasises that, although salvation is always by faith, 'the amount of knowledge one had of the future death of Christ was limited, and thus the content of faith was different at different stages of God's progressive revelation'.

Matthew 4:17 records the start of Jesus' public ministry as 'From that time Jesus began to preach and to say "Repent, for the kingdom of heaven is at hand."' On the same day the work of the Holy Spirit, performed through the Son of David, is blasphemed, Jesus announces that the only sign this evil and adulterous generation will be given, is the sign of the

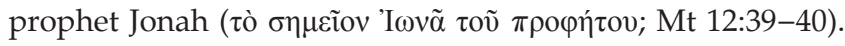
Shortly afterwards, when God the Father reveals to Peter the identity of Christ, a well-known structural marker in Matthew's Gospel is reached (cf. Kingsbury 1975:7-25) when Jesus' ministry is again described as 'From that time Jesus began to'. However, it was now focusing on the content of the gospel after the cross in terms of the great commission, namely Christ's death, burial and resurrection (Mt 16:16, 21; cf. 17:22-23; 20:17-20).

Does Matthew's use of the term kingdom of heaven change after this generation's blasphemy of the Holy Spirit? If it did, one might logically expect Matthew to provide some explanation, but because none is given, the term kingdom of heaven is best interpreted as still referring to the messianic kingdom (cf. Beacham 1996:233; Toussaint 1980:173-176). If Jesus is, however, not going to exercise his right to rule as the Davidic king until a future generation of Jews accepts him as their Messiah-King (cf. Mt 23:39), has the nature of the kingdom of heaven unalterably been changed into a spiritual 
kingdom only? On the same day the unpardonable sin was committed, Jesus announces the mysteries of the kingdom

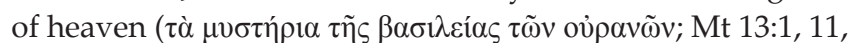
36, 53). Commenting on Matthew 13, Saucy (1997; cf. Peters 1972:622-623) points out:

This is not to say that the original character of the Kingdom as Jewish, historical, and political was necessarily abandoned with the mystery-teaching of the Kingdom. Rending the physical from the spiritual is the non-chiliast's error ... the error Jesus repudiates in his particular teaching on the Kingdom's futurity. (p. 335)

It is submitted that, from Pentecost until Christ's return, the kingdom exists spiritually in terms of the New covenant, but this does not abrogate God's unconditional promises regarding the Davidic kingdom, which is yet to be restored and established in terms of the Davidic covenant (Scholtz 2013:87-88). The fulfilment of the old prophecies regarding the establishment of the kingdom of heaven in terms of the Davidic covenant has been postponed. However, from Pentecost onwards, Christ as High Priest is already dispensing, by the Holy Spirit, spiritual blessings of the kingdom of heaven to his followers in terms of the New covenant. The parables of Matthew 13 may contain new content of a specific, prophetic and sometimes eschatological nature regarding this present age, juxtaposed with unfulfilled, old prophecies regarding the promised Davidic kingdom, which is yet to be restored in the age to come (Scholtz 2013:3).

\section{Implications for Matthew 10}

In light of the above, what implications are relevant to an interpretation of Matthew 10? In the first instance, two distinct mission assignments with different content of the gospel may be in view. In terms of the first mission, described in Matthew 10, the King authorises messengers to preach the gospel of the kingdom when the establishment of the kingdom of heaven in terms of the Davidic covenant is near (Mt 10:5b-42). As argued above, this first mission has been postponed and new instructions may be needed for a new mission, because Christ was rejected. In the second mission, the Lord commands the Church to make disciples out of all the nations (Israel included), preaching the gospel of Christ's death, burial and resurrection from Pentecost onwards (cf. Mt 16:21; 28:16-20). When the great commission has been completed, the first mission will be resumed and the gospel of the kingdom will once again be preached during the Tribulation. The Jewish generation living at the end of the Tribulation will accept Christ with the words, 'Blessed is $\mathrm{He}$ who comes in the name of the LORD!' (Mt 23:39; cf. Hs 5:15; Zch 12:10; Toussaint 1980:265-266; Fruchtenbaum 1989:618).

Secondly, the postponed Davidic kingdom could not again have been near until that generation in Israel had been judged for its national sin of blaspheming the Holy Spirit. With the benefit of hindsight, this judgment came in $70 \mathrm{AD}$. Consequently, the Church did not preach the gospel of the kingdom to the generation in Israel that rejected Jesus. In agreement with the comments of Ger (2004:67) on Acts 3, 'Peter's purpose was not to once again offer the already postponed kingdom to Israel, but to relay the circumstances under which that delayed kingdom can finally be established.' What Christ said would be given to 'that evil and adulterous generation', was the sign of the prophet Jonah, a veiled reference to the content of the gospel during the great commission. This is what the Church is preaching from Pentecost until the great commission ends - to the Jew first, but also to the Gentile. According to the argument presented and in disagreement with Carson (1995:252-253) and Hagner (2000:278-280), the period to which Matthew 10:16-23 refers, cannot include the time from Pentecost until the destruction of Jerusalem in $70 \mathrm{AD}$ as they claim. Commenting on Matthew 10:16-23, Wiersbe (1980:89) notes, 'We, today, can learn from these words, even though their primary interpretation and application are for God's servants at a future time.'

Thirdly, if the content of the gospel the Church is commanded to preach, focuses on Christ's death, burial and resurrection (cf. 1 Cor 15:1-4), who will in future preach the gospel of the kingdom and when will it occur? Although the Church partakes of the spiritual blessings of Israel's unconditional Abrahamic, Land, Davidic and New covenants, the body of Christ does not take these covenants over or replace Israel (Eph 2:11-16;3:5-6; cf. Rm 9:4; 11:17, 24). These unconditional covenants belong to Israel. Because it is required that a Jewish generation call on the Son of David to return and establish the kingdom (Mt 23:39), it is submitted that during the Tribulation the gospel of the kingdom must be preached by Jewish messengers authorised by the King of the Jews. It therefore appears that the prophetic content of Matthew 10:16-42 refers to the Tribulation period, not the Church age. If so, then in disagreement with Nolland (2005:427-429), the period to which Matthew 10:16-23 refers does not include the Church age and the Tribulation as he alleges, but only to the Tribulation period. This may explain the distinct Jewish flavour of Matthew 10 and also the view that the next time the gospel of the kingdom is preached, it will be during the Tribulation (Mt 24:14). According to Bailey (1998),

Twice the ministry of Jesus had been couched in terms of the Old Testament expectation (4:23; 9:35). But after chapter 13 such vocabulary was no longer associated with Him until it was used again with reference to the Second Coming (Matt. 24-25; 26:29). The same could be said of the "nearness" language of the

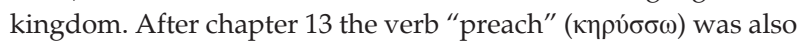
no longer used by Matthew to describe Jesus' ministry. (p. 176)

\section{Scofield's (cited in Couch 2000) comment is likewise relevant:}

Two preachings of this Gospel [of the kingdom] are mentioned, one past, beginning with the ministry of John the Baptist, continued by our Lord and His disciples, and ending with the Jewish rejection of the King. The other is yet future (Matt. 24:14), during the great tribulation, and immediately preceding the coming of the King in glory. (p. 196)

Fourthly, because Matthew 10:16-23 constitutes a unit, Carson (1995:252) rightly warns that verse 23 should not be detached, either from its immediate context (vv. 16-22) or 
from the historical context of the 12 disciples. If Matthew $10: 16-23$ is viewed as prophetically referring to the Tribulation period only (cf. Wiersbe 1980:87-89; Toussaint 1980:141-142), then verse 23 cannot be detached from 10:16-22. Further, had this generation heeded the King and the gospel of the kingdom (which they did not) at least 11 of the 12 apostles would have preached the gospel of the kingdom in the Tribulation period.

\section{The structure of Matthew 9:36-11:1a}

Assuming a narrative and transitional introduction (Mt 9:36-10:5a) and conclusion (Mt 11:1a), Hagner (2000:262-263) identifies the natural breaks in the mission discourse as follows: Matthew 10:5b-15, 16-23, 24-25, 26-31, 32-33, 34-39 and 40-42. Davies and Allison (1991:160-162) identify the same breaks, albeit via three major sections (Mt 10:5-25, 26-31, 32-42), with each section viewed as triadic (thus 5-15, 16-23 and 24-25; 26-31 with its three arguments, and then 32-33, 34-39, 40-42). France (2007:400) divides the discourse into three sections, namely Matthew 10:5-15, 16-23 and 24-42.

The breaks between Matthew 10:15 and 16 as well as between verse 23 and 24 need no elaboration. The statements in Matthew 10:24-25 explain why the disciples can expect persecution - leading to three encouragements not to fear (vv. 26-31) and a reminder why it is imperative that they hold firmly to their confession (vv. 32-33). The allusion to Micah 7:6 in Matthew 10:21 and its further quotation in 10:35-36 provide a basis for viewing 10:16-23 and 10:34-39 as chiastic parallels. The reception or rejection of the messengers of the King, first mentioned in Matthew 10:11-15, is used to conclude this mission discourse (10:40-42). See Figure 1 for the proposed chiastic structure for the mission discourse.

In the next section, a detailed exegesis of the mission discourse in Matthew 10 is not presented, but only a brief overview is given in line with the argument presented as well as the chiastic structure and its headings.

\section{Overview of Matthew 10:5b-42}

Jesus is moved with compassion, because the multitudes are like sheep without a shepherd and he commands the disciples to pray the Lord of the harvest to send out workers into his harvest field (Mt 9:36-38). From amongst those that were told to pray, 12 apostles were chosen and given the power to authenticate their divine mission (Mt 10:1-5a; cf. v. 8).

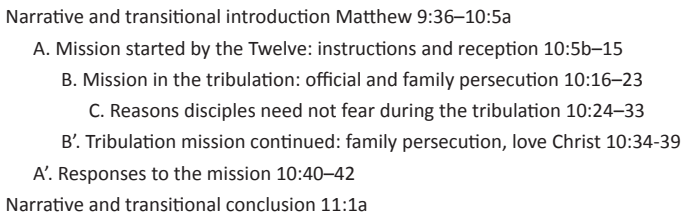

Source: Author's own construction

FIGURE 1: Chiastic structure.

\section{' $A$ ' Mission started by the Twelve: Instructions and reception (Mt 10:5b-15)}

The mission assignment (Mt 10:5b-15) begins by outlining its scope (vv. 5b-6), the content of the gospel and authenticating signs (vv. 7-8), provisions (vv. 9-10) and anticipated responses (vv. 11-15). Because a servant is not above his master, the initial scope of this mission on which the 12 apostles embarked cannot exceed the scope of their Master, who, at that time, had been sent only to the lost sheep of the

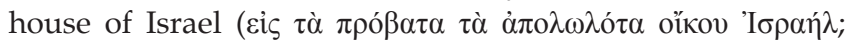
Mt 15:24). The messengers may authenticate the gospel of the kingdom with signs and they have to make no provisions, because a worker is worthy of his food. Those individuals or towns that reject these messengers will face judgment.

\section{' $B$ ' Mission in the Tribulation: Official and family persecution (Mt 10:16-23)}

The same mission on which the 12 apostles embarked will be resumed during the Tribulation period. Edersheim (1993) emphasises the Jewishness of this mission discourse:

[S] heep in the midst of wolves [is] a phrase which the Midrash applies to the position of Israel amidst a hostile world ... Similarly, the admonition to "be wise as serpents and harmless as doves" is reproduced in the Midrash, where Israel is described as harmless as the dove towards God, and wise as serpents towards the hostile Gentile nations. (p. 443)

Hagner (2000:276-277) notes that "while "sheep" in Matthew usually refers to those who are lost (e.g. 9:36; $10: 6 ; 15: 24 ; 18: 12$ ) here and in $26: 31$ it refers to the disciples (cf. 25:32-33)'. The Tribulation will be a time unlike any other since the beginning of the world (Mt 24:21), but the gospel of the kingdom will be preached as a witness to the

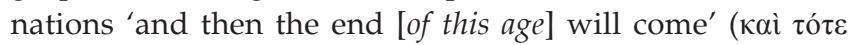

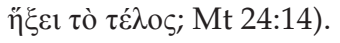

These messengers of the King must be both prudent and innocent (Carson 1995:247), both tough-minded and tenderhearted (Wiersbe 1980:88), as people will hand them over

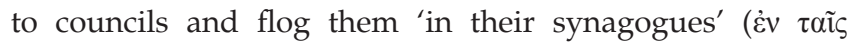

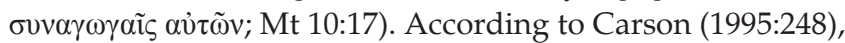
given the reference to 'their' synagogues, the disciples are handed over by Jews to Jews. During the Tribulation, however, the disciples will also be brought before governors

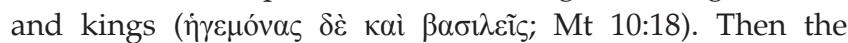
disciples will receive what to say by the Spirit of their Father who will speak through them (Mt 10:19-20).

The persecution of these Jewish disciples will extend from family members to all people, 'irrespective of race, color or creed' (Carson 1995:250), who will hate them for the sake of Christ's name (Mt 10:22). Referring to the Great Tribulation as the time when the Antichrist will bring worldwide persecution against God's people, Yates (2006:88) rightly states that such 'global tribulation hardly reflects the localized situation of A.D. 70, John's day or shortly thereafter'. Although the disciples can flee persecution by going from one town to another, they will not have gone through all the 
towns of Israel by the time the Son of Man comes at the end of the Tribulation (Mt 10:23; cf. 24:29-30).

\section{' $C$ ' Reasons encouraging disciples not to fear during the Tribulation (Mt 10:24-33)}

Arguing from the greater to the lesser, if the Master of the house has been called Beelzebub, the servants can expect no better treatment (Mt 10:24-25; cf. 9:34). Persecution is to be expected, but the King's messengers are not to fear: all will be revealed and made known (Mt 10:26-27); enemies can only kill the body, but not the soul (Mt 10:28); and the children of God the Father are of value to him (Mt 10:29-31). If the servants confess Christ before men, he will declare to God the Father that they belong to him (Mt 10:32-33).

\section{'B' 'Tribulation mission continued: Family persecution, love Christ (Mt 10:34-39)}

There will be no peace on earth until the Prince of peace returns to establish the Davidic kingdom. For that reason, the Lord said that he had not come to bring peace, but a sword

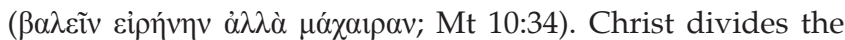
human race based on whom they love, follow and are loyal to. Such a division extends to family relationships, even to

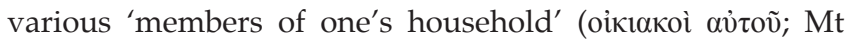
10:35-36; cf. Mi 7:6). The choice must be made however: Christ supreme, or not at all. No relationship should be chosen or placed before that of loving Christ. Anticipating the cross, and therefore even martyrdom, the disciples either sacrifice for Christ or serve themselves. Serving oneself, however, leads not to life, but is the very forfeit of it; losing one's life for Christ is the very finding of it (Mt 10:37-39).

\section{' $A$ ' ' Responses to the mission (Mt 10:40-42)}

At the end of the harvest, the Master of the house will reward believers based on how they treated his messengers. Those that receive his messengers receive the coming King and God the Father who sent him (Mt 10:40). This is true of those who responded to the 12 apostles (Mt 10:5b-15) and to the Tribulation messengers (Mt 10:16-39). In Matthew 10:40-42, the judgment focuses only on those who accepted the messengers (in Matthew's presentation, 'this generation' in Israel had not yet made its decision regarding the Messiah), corresponding to the sheep that Christ will separate from the goats when he returns (Mt 25:31-46). Comparing both Matthew 10:5b-15 and 10:40-42 with Matthew 25:40, 45, Pond (2002) remarks that the links are fivefold:

(a) $[T]$ he reference to "one" and "these," (b) the diminutive "little ones" (in place of "the least"), (c) the expression of hospitality, (d) the identification of Christ with the one being received, and (e) the promise of reward to the one who receives the little one. Based on these similarities, a mission background can be assumed for the interpretation of Matthew 25:31-46. (p. 439)

Those who received John the Baptist, a prophet ( $\pi \rho \circ \varphi \eta$ in; Mt 11:9) who came in the way of righteousness, will receive a prophet's reward ( $\mu 1 \sigma \theta$ òv $\pi \rho \circ \varphi \eta$ iov ; Mt 10:41a). Those who will receive the prophet Elijah during the Tribulation 4.Some may view this section as CDC', that is, verses $24-25,26-31$ and then $32-33$. will likewise receive a prophet's reward (Mt 10:41a; 17:11; cf. Ml 4:5-6). Since they are told to 'come up here' ('Avóß $\beta \tau \varepsilon \tilde{\omega} \delta \varepsilon)$ and then ascend into heaven ( $\operatorname{Rv} 11: 12)$, the two witnesses of Revelation 11 can certainly be viewed as righteous, and anyone who receives them, or other righteous messengers, even in their name, will receive 'a righteous man's reward'

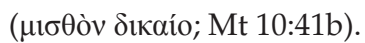

Like the other responses, those responding to the little ones are not saved by their works, but their works are evidence of their saving faith. In Matthew 10:42, 'the little ones' ( $\tau \tilde{\omega} v$ $\mu$ the gospel of the kingdom. As the worst ever persecution will occur during the Tribulation, hospitality and acts of compassion to these little ones will be rewarded (Mt 10:42; 24:21-22; 25:34-40).

\section{Conclusion}

This article proposed that the mission discourse in Matthew 10 be viewed as a single mission assignment covering two distinct periods when the gospel of the kingdom is preached. This perspective may provide a consistent and contextually coherent explanation for Matthew 10:23. A chiastic structure for Matthew 9:36-11:1a has also been proposed and the text was briefly discussed. During Christ's first advent, the Jews hardly heard the footsteps of the Messiah and the establishment of the messianic kingdom in terms of the Davidic covenant has been postponed. Currently, the Church has been commanded to make disciples out of all the nations by preaching the gospel of Christ's death, burial and resurrection. During the Tribulation that generation of Jews will not only hear the gospel of the kingdom, but they will respond by saying 'Blessed is he who comes in the name of the LORD!' Then all will see the Son of Man coming on the clouds of heaven with power and great glory.

\section{Acknowledgements}

\section{Competing interests}

The author declares that he has no financial or personal relationship(s) which may have inappropriately influenced him in writing this article.

\section{References}

Bailey, M.L., 1998, 'The parable of the sower and the soils', Bibliotheca Sacra 155(618), 172-188.

Barbieri, L.A., 1983, 'Matthew', in J.F. Walvoord \& R.B. Zuck (eds.), The Bible Knowledge Commentary: New Testament, pp. 13-94, David C. Cook, Colorado Springs.

Barrick, W.D., 2012, 'The kingdom of God in the Old Testament', The Master's Seminary Journal 23(2), 173-192.

Beacham, R.E., 1996, 'Universal and Mediatorial kingdoms', in M. Couch (ed.) Dictionary of premillennial theology, pp. 235-237, Kregel Publications, Grand Rapids.

Carson, D.A., 1995, Matthew chapters 1 through 12, Zondervan Publishing House, Grand Rapids. (The expositor's Bible commentary with the New International Version of the Holy Bible).

Constable, T.L., 2014, Notes on Matthew, 2014 edn., viewed 11 April 2014, from http://www.soniclight.com

Couch, M., 2000, 'Salvation in the dispensation of the Church', in M. Couch (ed.), An introduction to classical evangelical hermeneutics: $A$ guide to the history and practice of biblical interpretation, pp. 192-198, Kregel Publications, Grand Rapids.

Davies, W.D. \& Allison, D.C., 1991, A critical and exegetical commentary on the Gospel according to Saint Matthew, vol. 2, T\&T Clark, Edinburgh. (International Critical Commentary). 
Edersheim, A., 1993, The life and times of Jesus the Messiah: New updated version, Hendrickson Publishers, Peabody.

France, R.T., 2007, The Gospel of Matthew, William B. Eerdmans Publishing Company, Grand Rapids.

Fruchtenbaum, A.G., 1989, Israelology: The missing link in systematic theology, Arie Ministries, Tustin.

Ger, S., 2004, The Book of Acts: Witnesses to the world, AMG Publishers, Chattanooga.

Hagner, D.A., 2000, Matthew 1-13, Thomas Nelson, Nashville. (WBC Commentary $33 A)$.

Kingsbury, J.D., 1975, Matthew: Structure, Christology, Kingdom, Fortress Press, Minneapolis.

McAvoy, S.L., 1996, 'Abrahamic covenant', in M. Couch (ed.), Dictionary of premillennial theology, pp. 27-32, Kregel Publications, Grand Rapids.

McClain, A.J., 1959, The greatness of the Kingdom: An inductive study of the Kingdom of God, BHM Books, Winona Lake.

Nolland, J., 2005, The Gospel of Matthew: A commentary on the Greek text, William B. Eerdmans Publishing Company, Grand Rapids. (The New International Greek Testament commentary).

Pentecost, J.D., 1991, The words and works of Jesus Christ, Zondervan, Grand Rapids.

Pentecost, J.D., 1995, Thy Kingdom come: Tracing God's Kingdom program and covenant promises throughout history, Kregel Publications, Grand Rapids.

Peters, G.N.H., 1972, The Theocratic Kingdom, vol. 1, Kregel Publications, Grand Rapids.
Pond, E.W., 2002, 'Who are "the least" of Jesus' brothers in Matthew 25:40?' Bibliotheca Sacra 159(636), 436-448.

Ryrie, C.C., 2007, Dispensationalism, Moody Publishers, Chicago.

Saucy, M.R., 1997, The kingdom of God in the teaching of Jesus: In 20th century theology, Word Publishing, Dallas.

Selman, M.J., 1989, 'The kingdom of God in the Old Testament', Tyndale Bulletin 40(2), 161-183.

Scholtz, J.J., 2013, 'Collective meaning and specific, prophetic reference for the parables of Matthew 13?', Unpublished MTh thesis, Stellenbosch University viewed 11 April 2014, from http://scholar.sun.ac.za/handle/10019.1/85594

Stallard, M., 2000, 'Hermeneutics and Matthew 13 Part 1', Conservative Theological Journal 5, 131-154.

Toussaint, S.D., 1980, Behold the King: A study of Matthew, Kregel Publications, Grand Rapids.

Toussaint, S.D., 1994, 'The contingency of the coming kingdom', in C.H. Dyer \& R.B. Zuck (eds.), Integrity of heart, skilfulness of hands: Biblical and leadership studies in honor of Donald K. Campbell, pp. 222-237, Baker Books, Grand Rapids.

Toussaint, S.D. \& Quine, J.A., 2007, 'No, not yet: The contingency of God's promised kingdom', Bibliotheca Sacra 164(654), 131-147.

Wiersbe, W., 1980, Be loyal: Following the King of kings, David C Cook, Colorado Springs.

Yates, R.S., 2006, 'The identity of the Tribulation saints', Bibliotheca Sacra 163(649), 79-93. 